\title{
Responses of the Whitefly Bemisia tabaci (Hemiptera: Aleyrodidae) to Biologically Based Insecticides
}

\author{
Hail Kamel Shannag ${ }^{1,}$, Malak Saleh Al-Haj ${ }^{1}$, John Lowell Capinera ${ }^{2}$ \\ ${ }^{1}$ Faculty of Agriculture, Jordan University of Science and Technology, Irbid, Jordan \\ ${ }^{2}$ Institute of Food and Agricultural Sciences, University of Florida, Gainesville, United States \\ Email address: \\ hail@just.edu.jo (H. K. Shannag), Malekab84@yahoo.com (M. S. Al-Haj), capinera@ufl.edu(J. L. Capinera) \\ *Corresponding author
}

\section{To cite this article:}

Hail Kamel Shannag, Malak Saleh Al-Haj, John Lowell Capinera. Responses of the Whitefly Bemisia tabaci (Hemiptera: Aleyrodidae) to Biologically Based Insecticides. American Journal of Entomology. Vol. 2, No. 3, 2018, pp. 28-35. doi: 10.11648/j.aje.20180203.12

Received: October 4, 2018; Accepted: October 19, 2018; Published: November 10, 2018

\begin{abstract}
The effects of three bio-insecticides Azatrol [neem: 1.2\% azadirachtin A and B], Molt-X [neem: 3\% azadirachtin], and Conserve SC [spinosad; 11.6\% spinosyn A and spinosyn D], applied at different concentrations were evaluated on Bemisia tabaci (Gennadius) (Hemiptera: Aleyrodidae) under both laboratory and greenhouse conditions. Laboratory bioassays demonstrated that both neem-based insecticides were repellent to adult whiteflies in a dose-dependent manner. The amounts and frequency of honeydew excretion were significantly reduced up to 0.95 by foliar application of these insecticides at the labeled rate, as compared to untreated plants, with the neem products displaying greater effects on food uptake than spinosad. Reduced fecundity and egg hatch also were associated with these bio-insecticides. The bio-insecticides decreased significantly the survival of nymphs, egg hatch and adult emergence when applied systemically via the roots. However, the impacts of neem-based insecticides on all parameters tested were greater than that of spinosad. The results indicate that the biologically based formulations tested were effective in suppressing whitefly abundance and acting as an efficient repellent, though they were not able to completely inhibit food intake. The repellent and antifeedant activities of such natural products render plants unattractive to $B$. tabaci, thus potentially reducing the incidence of viral diseases transmitted by this pest. The systemic properties of these formulated biopesticides minimize their rapid degradation by strong ultraviolet light and their adverse effects on non-target organisms.
\end{abstract}

Keywords: Whitefly, Bemisia tabaci, Biopesticides, Cucumber, Azadirachtin

\section{Introduction}

The agricultural sector of Jordan is one of the most important economic pillars for integrated development in Jordan, constituting $16 \%$ of the country's exports [1]. One of the major strengths of the indigenous agriculture is the potential for growing a wide variety of vegetables and fruit trees. However, infestation by pestiferous insects is one of the main constraints for crop productivity in the country, among them the whitefly Bemisia tabaci (Gennadius) (Hemiptera: Aleyrodidae). This pest is found worldwide, where it produces several generations per year and attacks hundreds of plant species in numerous plant families grown both in the field and under greenhouse conditions [2-3]. It is considered a species complex due to its variability. $B$. tabaci can inflict severe injury directly by depriving the plant of its essential nutrients, eventually resulting in a wilting, deformed plant with premature leaf senescence and retarded growth [4]. It also disrupts the host plant by injecting toxic saliva while feeding on the plant; this causes physiological changes in plant tissue such as uneven ripening of tomato fruits and discoloration of cucurbit foliage [5-6]. Indirect damage can arise from the contamination of fresh-market crops with honeydew and sooty mold, which adversely affects some physiological processes in the host plant and may renders crops unsaleable [7]. Furthermore, B. tabaci is one of the most important vectors of several plant viruses throughout the world [8-9].

To preclude the injury caused by the whitefly, growers tend to combat this pest with indiscriminate application of conventional insecticides. However, this approach is imperfect because oviposition and growth of the whitefly 
nymphs occur beneath leaf surfaces [10], and the difficulty of controlling insects under such circumstances often necessitates repeated spraying of hazardous toxins. Such intensive usage of agrochemicals may lead to elimination of the whitefly's natural enemies, favor the selection of resistant individuals, raise production costs, and increase environmental pollution and negative health effects. Thus, development of novel, effective, and practical approaches based on enhancing the use of biologically based insecticides to control arthropod pests on different economic crops may lead to the development of sustainable pest management systems for many crops, which are essential for increasing safe production and protecting the environment.

Many plants contain bioactive chemicals that may provide alternatives to the traditional insecticides [11]. Commercial products based on neem extracts have been used effectively in many cropping systems to complement natural enemies for integrated pest management due to their selectivity, low toxicity, and biodegradable properties. They act as potent insect growth regulators for insects [12], and affect the feeding behavior, fecundity, growth, fitness, and mobility of insects under field and greenhouse conditions [13]. Different neem-based formulations have been shown to have activity against specific nymphal stages of $B$. tabaci, particularly on tomato [14-17]. Because neem extracts are used principally for foliar treatment, where sunlight can degrade the product, erratic levels of success have been reported on arthropod pests [18]. However, by making use of the systemic properties of azadirachtin, soil treatment is one of the options that may reduce instability and prolong persistence of these products [14-15]. Another benefit derived from soil drenching with neem-based insecticides is the reduction of direct toxicity to natural enemies, thereby allowing the use of a complementary component for integrated pest management.

Spinosad is based on a fermentation product of the soil bacterium Saccharopolyspora spinosa. There are over 20 natural forms of spinosyns, and over 200 synthetic forms, called spinosoids [19]. It is toxic to arthropod targets by ingestion and contact, and has a unique mode of action on the insect nervous system [20]. Spinosad exhibits a high degree of selective toxicity to the insects of many orders, but it has little toxicity to many beneficial arthropods, people, other vertebrate animals, and the environment [20].

Because $B$. tabaci is a species complex undergoing evolutionary change, existing biotypes of $B$. tabaci exhibit dissimilarity in response to agrochemicals. Furthermore, the effect of neem products on insect performance is inconsistent among different commercially formulated products. Therefore, a study was conducted to determine the effect of three bioinsecticides applied at different concentrations on $B$. tabaci feeding on cucumber plants. The effects of different treatments on repellency, food uptake, fecundity, and fertility of B. tabaci were evaluated. Systemic properties were calculated, following soil drenching on the survival of eggs, nymphs, and on adult emergence.

\section{Materials and Methods}

\subsection{Whitefly Colony}

A colony of whiteflies was established from individuals collected from a field in the Irbid district, Jordan. The whiteflies were maintained on young pea plants grown in peat moss-filled plastic pots $(15 \mathrm{~cm}$ in diameter $)$ under controlled conditions at $25 \pm 3^{\circ} \mathrm{C}$ with a $16: 8 \mathrm{~h}(\mathrm{~L}: \mathrm{D})$ photoperiod. B. tabaci was kept in cages with an aluminum frame $(140 \mathrm{~cm} \mathrm{H} \times 85 \mathrm{~cm} \mathrm{~W} \times 130 \mathrm{~cm} \mathrm{~L})$ covered with muslin gauze from all sides and above. A continuous supply of new pea plants was provided, as needed, for colony maintenance.

\subsection{Experimental Plants}

Cucumber seeds obtained from local market were pregerminated for three days in plastic Petri dishes $(9 \times 1.5 \mathrm{~cm})$ lined with wet filter paper. Subsequently, seeds were planted individually in plastic seedling trays $(50 \times 30 \times 6.6 \mathrm{~cm})$ containing a commercial peat moss substrate at the rate of 50 seeds per tray. After growing for about 7 days under greenhouse conditions, seedlings in the primary leaf stage were independently transplanted into a plastic pot $(15 \mathrm{~cm}$ in diameter) filled with peat moss and then maintained in a greenhouse at $25 \pm 3^{\circ} \mathrm{C}$ until they were used in the relevant experiments. Experimental plants were fertilized weekly with 20-9-20 water-soluble fertilizer (N-P-K) and irrigated as needed.

\subsection{Formulated Bio-Pesticides}

Two types of commercial formulated neem-based insecticides, Azatrol (1.2\% azadiractin A and B) and Molt-X (3\% azadiractin), were obtained from Pbi/Gordon Corporation, Kansas City, Missouri, USA and BioWorks Inc, Victor, New York, USA, respectively. Another novel insecticide, Conserve SC (spinosad containing 11.6\% spinosyn A and spinosyn D) was obtained from Dow AgroSciences LLS, Indianapolis, Indiana, USA. Each of these insecticides is listed for use in organic production in the United States of America. The efficacy of these three natural products, each applied at three different concentrations, was evaluated for effects on whiteflies feeding on cucumber plant under greenhouse and laboratory conditions. Concentrations evaluated were 8.5, 17, and $25.5 \mathrm{ml} / 1$ for Azatrol, 0.4, 0.8, and $1.2 \mathrm{ml} / 1$ for Molt-X, and 3, 6, and $9 \mathrm{ml}$ for Conserve SC. These concentrations represent $1 / 2,1 / 1$, and $11 / 2$ of the recommended rate for each product, respectively.

\subsection{Laboratory Bioassays}

Repellent activity of the neem-based formulations, namely Azatrol and Molt-X, was examined under controlled conditions at $25 \pm 3^{\circ} \mathrm{C}$ and a photoperiod of $14: 10 \mathrm{~h}$ (L: D). Cucumber seedlings at the first true leaf stage grown separately in peat moss-filled pots were used for each bioassay test. The aerial portion of each seedling was sprayed thoroughly by hand sprayer with neem-based product 
prepared at three different concentrations. Seedlings were then left to dry at room temperature for one hour. Control plants were treated in a similar manner with tap water.

Repellency was assessed using choice tests. Two-choice tests used plants treated with one of the neem products and an untreated (control) plant, whereas in multiple-choice tests both neem products and the control were offered simultaneously to adult whiteflies. The two or three cucumber seedlings, depending on the test were arranged randomly beneath a transparent plastic box $(60 \mathrm{~cm} \mathrm{~L} \mathrm{x} 40 \mathrm{~cm}$ W $x 40 \mathrm{~cm} \mathrm{H}$ ) enclosing the experimental plants and whiteflies. In this experiment, neem-based insecticides were only used at recommended field concentrations for cucumber. The seedlings within each pot were tagged based on neem product, and the bottom of the container was partitioned into two or three equal areas, with each labelled to correspond with the seedling treatment. Thirty same-aged adult whiteflies obtained from a synchronized colony were released at the center of each container using a fine, moist camel-hair brush, and allowed to settle freely on each plant or on inner surfaces of the enclosure (container) for both twochoice and multiple-choice tests. The number of whiteflies colonizing treated and control plants were counted after an exposure period of 24 hours. Each concentration of either product was replicated 10 times within each choice test. Percent repellency in choice tests was calculated using the following equation:

$\%$ repellency $=$ (number of individuals in untreated plant number of individuals in treated plant) / total numbers of individuals $\times 100$.

No-choice tests also were conducted. In no-choice assays, a plexi-glass cylinder $(25 \mathrm{~cm}$ diameter $\times 25 \mathrm{~cm}$ height $)$ was lowered over an individual seedling of each treatment, and then 30 adult whiteflies were introduced into each cylinder. The number of adult insects that had settled on each experimental plant was recorded 24 hours after release. Each treatment was replicated 10 times.

\subsection{Food Uptake}

To identify the effect of the formulated bio pesticides on the feeding activity of adult whiteflies, the amount of honeydew secreted by same-aged adult whiteflies was quantified. In this study, eight individual plants were treated with either Azatrol, Molt-X, or Conserve at recommended application rates, $17,0.8$ and $6 \mathrm{ml} / \mathrm{l}$, respectively, using a hand-held sprayer until runoff. Plants sprayed only with tap water served as a control. The treated plants were left to dry in the laboratory for about two hours, then the second leaf of each plant was artificially infested with 20 adults obtained from a synchronized colony.

Released whiteflies were confined on the leaf undersurface by a clip-on cage made of a plastic Petri dish $(6 \times 1.5 \mathrm{~cm})$ with two holes on the sides covered with fine mesh cloth for ventilation. Each clip-on cage was lined on the bottom with a spherical piece of aluminum foil precisely fitting its internal bottom surface after determining its initial weight using a digital microbalance (Mittler Electronic Microbalance with
$0.0001 \mu \mathrm{g}$ accuracy). After feeding for 24 hours, cages were detached from plant and the aluminum foil pieces were individually weighed again. The total amount of honeydew produced by 20 adults per cage was calculated by subtracting the initial weight from the final one.

To assess the frequency of honeydew secretion by adult whitefly, experimental plants were treated with formulations as described above. Once insecticide residues dried, 50 sameaged adults of $B$. tabaci were introduced into the undersurface of the full-expanded second leaf of cucumber plant. Following the adult colonization, a modified wall clock lined on the front surface with a paper sheet treated uniformly with a $\mathrm{pH}$ indicator, $0.04 \%$ aqueous Bromocresol Green $(0.1 \mathrm{~g}$ of bromocresol green in $75 \mathrm{ml}$ of ethyl alcohol), was maintained for $24 \mathrm{~h}$ beneath the leaf occupied with adults with treated paper facing the leaf undersurface of the infested leaf. Each treatment was replicated four times. Numbers of honeydew drops that had fallen onto the treated paper were counted at one-day intervals.

\subsection{Fecundity and Fertility of Whitefly}

To evaluate the impact of three bio-insecticides on the fecundity and fertility of whiteflies, cucumber plants at the second true leaf stage were sprayed with either Azatrol, Molt-X or Conserve at a standard concentration of $17 \mathrm{ml} / \mathrm{l}$, $0.8 \mathrm{ml} / 1$ for Molt-X, or $6 \mathrm{ml} / 1$, respectively, until run-off, while plants treated with tap water represented control. After 1-2 hours drying period under controlled room conditions, the second fully expanded leaf of each experimental plant was exposed to 5 pairs of one-day-old whitefly adults (5 females and 5 males) for 5 days in a clip-on cage made of a plastic Petri dish $(6 \mathrm{~cm} \times 1.5 \mathrm{~cm})$ positioned at the leaf undersurface. Subsequently, clip-on cages and adult whiteflies were removed and the numbers of oviposited eggs were recorded for each cage. After incubation for an additional 7 days, the numbers of hatched and dead eggs were determined.

\subsection{Effect of Soil Drenching with Bio-insecticides on B. tabaci}

Two weeks-old cucumber plants planted individually in peat moss-filled plastic pot were drenched with appropriate bio-pesticide products prepared at three different concentrations, whereas plants grown in the non-amended soil served as control. Treatments used in this investigation were as follow; 17, 25.5 and $34 \mathrm{ml} / 1$ for Azatrol; 0.8, 1.2 and $1.6 \mathrm{ml} / 1$ for Molt-X; and 6, 9 and $12 \mathrm{ml} / 1$ for the Conserve product. Each treatment was replicated eight times.

After allowing 24 hours for pesticide uptake, experimental plants were exposed to the whitefly colony for 3 days for oviposition. Thereafter, the whitefly adults were removed from the plants and the numbers of eggs laid on each plant were recorded. Then, experimental plants were kept under greenhouse conditions to permit further development of the deposited eggs. During the experimental period, mortality of eggs and first nymphal instar as well as the number of 
emerged adults were calculated.

Data were evaluated with analysis of variance using SAS software version 9.2 [21] and treatment means were compared by the Least Significance Differences (LSD) test at $\mathrm{P} \leq 0.05$. Mortality counts of whiteflies were computed through Schneider-Orelli's formula: corrected mortality (\%) $=[($ mortality $\%$ in treated plot - mortality $\%$ in control plot $) /$ $(100-$ mortality in control plot)] x 100 [22].

\section{Results}

The effects of two commercially available neem-based products on the colonization behavior of adult whiteflies using different bioassay tests are illustrated in Table 1. After one-day of exposure to treated plants, the settling behavior of whitefly adults was reduced noticeably by $0.53-0.90$, with higher concentrations more effective $(\mathrm{F}=269.95$; $\mathrm{df}=6,63$; $\mathrm{P}<0.0001)$. In two-choice assays, whiteflies given a choice of either treated or untreated cucumber plants had a lower tendency to colonize treated plants; both neem-based insecticides showed up to 0.68 repellency in non-choice tests with higher levels of repellency elicited by increasing concentrations $(\mathrm{F}=242.91 ; \mathrm{df}=6,63 ; \mathrm{P}<0.0001)$ (Table 1). Whitefly adults significantly favored untreated plants for settling in the multiple-choice tests when presented simultaneously with plants treated with bio-pesticide at the tested concentrations $(\mathrm{F}=156.89$; df $=2,27 ; \mathrm{P}<0.0001)$; however, the adults did not completely reject the neemtreated plants completely for colonization. Foliar spray with Azatrol or Molt-X decreased the occurrence of whitefly adults by 0.88 and 0.80 , respectively, compared to control (Table 1).

Table 1. Effect of two commercial available neem-based insecticides used at different concentrations on the settling behavior of adult whitefly using choice, non-choice, and multiple choice bioassays.

\begin{tabular}{|c|c|c|c|c|c|}
\hline Treatment & Concentration (ml/l) & Non-choice test & Choice test (\% repellency) & Non-choice test & Multiple choice test \\
\hline Control & 0 & $24.00 \pm 0.33 \mathrm{a}$ & - & $24.00 \pm 0.33 \mathrm{a}$ & $14.60 \pm 0.56 \mathrm{a}$ \\
\hline \multirow[t]{3}{*}{ Azatrol } & 8.5 & $9.90 \pm 0.35 \mathrm{c}$ & $42.33 \pm 1.22 \mathrm{~d}$ & $9.90 \pm 0.35 \mathrm{c}$ & - \\
\hline & 17 & $7.20 \pm 0.42 \mathrm{~d}$ & $53.66 \pm 1.75 \mathrm{c}$ & $7.20 \pm 0.42 \mathrm{~d}$ & $1.80 \pm 0.51 \mathrm{c}$ \\
\hline & 25.5 & $3.10 \pm 0.55 \mathrm{f}$ & $68.06 \pm 1.12 \mathrm{a}$ & $3.10 \pm 0.55 \mathrm{f}$ & - \\
\hline \multirow[t]{3}{*}{ Molt-X } & 0.4 & $11.30 \pm 0.30 \mathrm{~b}$ & $43.33 \pm 1.21 \mathrm{~d}$ & $11.30 \pm 0.30 \mathrm{~b}$ & - \\
\hline & 0.8 & $6.80 \pm 0.61 \mathrm{~d}$ & $57.33 \pm 1.38 \mathrm{~b}$ & $6.80 \pm 0.61 \mathrm{~d}$ & $3.00 \pm 0.61 b$ \\
\hline & 1.2 & $2.50 \pm 0.50 \mathrm{e}$ & $66.66 \pm 1.31 \mathrm{a}$ & $2.50 \pm 0.50 \mathrm{e}$ & - \\
\hline
\end{tabular}

Means within columns followed by the same letter are not significantly different at $\mathrm{P} \leq 0.05$.

All commercially formulated natural products demonstrated potential antifeedant properties to adult whiteflies, but at different magnitudes. Food intake by whiteflies on plants treated with Azatrol and Molt-X diminished significantly by 0.95 and 0.84 relative to the control, respectively, whereas whiteflies fed on plants treated with Conserve excreted 0.1 less honeydew compared to that kept on control plants (Table 2). There were significant differences among all treatments $(\mathrm{F}=43.01 ; \mathrm{df}=3,36 ; \mathrm{P}<0.0001)$. Frequency of honeydew production of adults was significantly reduced relative to the untreated plant, as indicated by the number of honeydew drops per $24 \mathrm{~h}$, with only a small effect attributable to spinosad $(\mathrm{F}=66.32 ; \mathrm{df}=3,36 ; \mathrm{P}<0.0001)$.

Table 2. Antifeedant activity of foliar treatment with different biopesticides used at recommended field rates under controlled conditions.

\begin{tabular}{lllc}
\hline Treatment & Concentration $(\mathbf{m l} / \mathbf{l})$ & Honeydew $(\mathbf{m g})$ / 50 adults & Frequency of honeydew production / 50 adults \\
\hline Control & 0 & $0.39 \pm 0.02 \mathrm{a}$ & $535.33 \pm 35.53 \mathrm{a}$ \\
Azatrol & 17 & $0.02 \pm 0.01 \mathrm{~d}$ & $230.00 \pm 5.03 \mathrm{c}$ \\
Molt-X & 0.8 & $0.06 \pm 0.03 \mathrm{c}$ & $184.33 \pm 9.21 \mathrm{~d}$ \\
Conserve & 6 & $0.35 \pm 0.03 \mathrm{~b}$ & $483.00 \pm 9.61 \mathrm{~b}$ \\
\hline
\end{tabular}

Means within columns followed by the same letter are not significantly different at $\mathrm{P} \leq 0.05$.

When same-aged females of whitefly were confined to freshly treated cucumber leaves for 5 days, a substantial decrease in fecundity was observed $(\mathrm{F}=65.90 ; \mathrm{df}=3,36 ; \mathrm{P}<0.0001)$. The number of eggs deposited by female whiteflies was reduced by $22.89 \%$ for Azatrol, $24.46 \%$ for Molt-X and only $3.8 \%$ for Conserve in comparison with the oviposition rate on control plants (Table 3). Fertility of whitefly eggs laid on treatment plants was also negatively affected $(\mathrm{F}=303.13$; df $=3,36$; $\mathrm{P}<$ 0.0001). The greatest reduction in percent egg hatch was associated with exposure to Molt-X (Table 3).

Table 3. Fecundity and fertility of the same-aged whitefly adults by exposure to fresh residues of different biological-based biopesticides applied at the field dosages.

\begin{tabular}{llll}
\hline Treatment & Concentration $(\mathbf{m l} / \mathbf{l})$ & No. of laid eggs & \% hatched eggs \\
\hline Control & 0 & $165.60 \pm 2.80 \mathrm{a}$ & $92.07 \pm 2.54 \mathrm{a}$ \\
Azatrol & 17 & $127.70 \pm 2.74 \mathrm{c}$ & $45.61 \pm 0.53 \mathrm{c}$ \\
Molt-X & 0.8 & $125.10 \pm 2.00 \mathrm{c}$ & $40.06 \pm 0.64 \mathrm{~d}$ \\
Conserve & 6 & $159.30 \pm 1.15 \mathrm{~b}$ & $70.76 \pm 0.50 \mathrm{~b}$ \\
\hline
\end{tabular}

Means within columns followed by the same letter are not significantly different at $\mathrm{P} \leq 0.05$. 
Soil treatment with the bio-pesticides showed that neembased insecticides had a perceptible systematic property as indicated by increased mortality of eggs and young nymphs, along with reduced numbers of adults emerging on sprayed plants. However, the effect on egg mortality varied from 0.14
- 0.53 (Table 4), depending on the chemical and concentration $(\mathrm{F}=53.12 ; \mathrm{df}=9,30 ; \mathrm{P}<0.0001)$. The effect on nymph mortality was quite similar to that on egg mortality, with variation attributable to the product and concentration $(\mathrm{F}=25.86 ; \mathrm{df}=9,30 ; \mathrm{P}<0.0001)$.

Table 4. Influence of soil drenching with three formulated biopesticides used at different concentration on the mortality rates of eggs and nymphs, along with proportion of emerged adults.

\begin{tabular}{|c|c|c|c|c|}
\hline Treatment & Concentration (ml/l) & Egg mortality (\%) & Young nymph mortality (\%) & Emerged adult (\%) \\
\hline Control & 0 & 0 & 0 & $89.95 \pm 1.74 \mathrm{a}$ \\
\hline \multirow[t]{3}{*}{ Azatrol } & 17 & $36.31 \pm 2.27 \mathrm{c}$ & $38.89 \pm 1.55 \mathrm{c}$ & $54.85 \pm 1.65 \mathrm{~d}$ \\
\hline & 25.5 & $50.84 \pm 1.04 \mathrm{a}$ & $54.27 \pm 5.44 \mathrm{a}$ & $44.11 \pm 3.20$ ef \\
\hline & 34 & $52.98 \pm 2.15 \mathrm{a}$ & $51.09 \pm 2.44 \mathrm{a}$ & $45.39 \pm 1.73 \mathrm{e}$ \\
\hline \multirow[t]{3}{*}{ Molt-X } & 0.8 & $46.49 \pm 1.74 \mathrm{~b}$ & $46.96 \pm 5.68 b$ & $47.49 \pm 4.49 \mathrm{e}$ \\
\hline & 1.2 & $52.75 \pm 2.81 \mathrm{a}$ & $54.01 \pm 4.26 \mathrm{a}$ & $41.25 \pm 3.42 \mathrm{fg}$ \\
\hline & 1.6 & $52.34 \pm 1.90 \mathrm{a}$ & $55.35 \pm 1.15 \mathrm{a}$ & $40.20 \pm 1.65 \mathrm{~g}$ \\
\hline \multirow[t]{3}{*}{ Conserve } & 6 & $14.42 \pm 2.25 \mathrm{~d}$ & $13.17 \pm 2.24 \mathrm{e}$ & $80.07 \pm 1.91 \mathrm{~b}$ \\
\hline & 9 & $16.08 \pm 2.48 \mathrm{~d}$ & $14.25 \pm 2.51 \mathrm{e}$ & $79.12 \pm 2.37 b$ \\
\hline & 12 & $16.84 \pm 3.41 \mathrm{~d}$ & $19.35 \pm 2.33 \mathrm{~d}$ & $74.48 \pm 1.73 \mathrm{c}$ \\
\hline
\end{tabular}

Means within columns followed by the same letter are not significantly different at $\mathrm{P} \leq 0.05$.

The proportion of adults that emerged successfully from eggs deposited on plants grown in treated soil was considerably reduced in comparison to emergence from insects feeding on plants grown in untreated soil (Table 4). The number of whiteflies that reached adulthood was a function of both the product and concentration $(\mathrm{F}=32.35$; $\mathrm{df}$ $=9,90 ; \mathrm{P}<0.0001)$.

\section{Discussion}

Whitefly management has traditionally depended on the use of synthetic insecticides. However, the increasing resistances of Bemisia species to pesticides, and their adverse effects on the environment, provide an impetus to use integrated pest control measures, including bio-pesticides and biological control to combat this pest. Bio-pesticides are based on natural products, which generally are more acceptable than conventional pesticides because of their reputation for being less hazardous to humans and other nontarget organisms [23].

Neem has almost legendary insect repellent and antifeedant properties due to its long use as a crop protectant in many countries [24]. The repellence of some botanical insecticides has emerged as a promising technique in the alternative control of urban and agricultural pests, being one component of integrated pest management. Likewise, antifeedants offer a novel approach to vector and disease management by rendering plants unattractive or unacceptable to pest insects [25].

This study showed that foliar application with commercially formulated neem-based Azatrol and Molt-X had a deterrent effect on B. tabaci in a concentrationdependent manner, resulting in fewer adults settling on treated cucumber plants compared to untreated controls. The level of repellency associated with fresh Azatrol residue was more conspicuous than that of Molt-X in multiple-choice test. Similar decreases in colonization of adult whiteflies following foliar and soil application of different neem-based formulations were also described for $B$. tabaci and $B$. argentifolii Bellowas and Perring (Hemiptera: Aleyrodidae) on different host plants [26 - 29]. Foliar, seed, and soil application of NeemAzal T/S and NeemAzalU reduced the colonization of tomato plants by $B$. tabaci adults and consequently reduced egg deposition, though no such effect was found with spinosad-based Success $[14,16]$. The host evaluation behavior of female $B$. tabaci adults is disturbed by azadirachtin application [29]; in addition of repellency of azadiractin to adult whiteflies, they display shorter duration and less frequent probing, and more frequent and longer periods of labial grooming on treated leaves than on untreated leaves.

There are numerous reports of different commercial neembased formulations affecting feeding by phytophagous insects with different feeding habits [30 - 31], though the outcomes are not always predictable. For example, in choice tests with formulated neem seed oil, the nymphs and adults of strawberry aphid, Chaetosiphon fragaefolii (Cockerell) (Hemiptera: Aphididae) were equally deterred from feeding, although its deterrent activity disappeared within 24 hours following treatment under greenhouse conditions [32]. On the other hand, application of some neem-based insecticides failed to deter the settling behavior of Myzus persicae (Sulzer) (Hemiptera: Aphididae) on treated leaf disks [31, 33]. Such disparate outcomes may be caused by differences in azadirachtin content in the various parts of the neem tree [34], as well as inherent differences in the insect species tested.

The bio-insecticides tested had a strong antifeedant activity on whitefly adults, often limiting the feeding activity on neem-treated leaf areas to a fraction of that occurring on controls. Azatrol and Molt-X were more potent antifeedants than Conserve; however, none of the three biopesticides entirely prevented feeding of whitefly, apparently because the active ingredients of these natural compounds are nonvolatile 
substances and the insect must taste them in order to respond to their presence [35]. The mechanisms underlying the antifeedant activity of neem insecticides were credited to a direct action of neem products on the centers of control that regulate feeding and metabolism [36] and/or the inhibition of feeding behavior by stimulation of deterrent chemoreceptors on the mouthparts, or blockage of input receptors for phagostimulants [37].

In addition to the deterrent and antifeedant properties of bio-pesticide products on young adults of $B$. tabaci, we observed as little as one-seventh the egg production by females fed with treated foliage, relative to untreated foliage However, Conserve was not as effective as Azatrol and Molt$\mathrm{X}$.

Systemic activity of commercial formulated neem-based insecticides has been reported in several studies in different herbivore-plant systems [38 - 40]. However, only a few earlier studies have used the active uptake by intact roots, rather than artificial loading of plants by immersion of cut stems or leaves in neem solution. Results of this study agree with earlier findings obtained for $B$. argentifolii [41], $B$. tabaci [14-15], western flower thrips, Frankliniella occidentalis Pergande (Thysanoptera: Thripidae) [43-43] and aphids (Hemiptera: Aphidae) [31, 44]. All these studies showed systemic translocation of neem after soil drenching to intact plants, resulting in strong effects on the sucking insects. Azatrol and Molt-X possessed relevant systemic activity to the whitefly as indicated by increased mortality of eggs and young nymphs in addition to reduction of the proportion of adults emerging.

Spinosad-based Conserve applied to the soil had a slight effect on egg and nymphal survival, along with emergence of B. tabaci adults. However, there is evidence of systemic activity of spinosad against Trialeurodes vaporariorum Westwood (Hemiptera: Aleyrodidae) on tomato plants [45] and spider mites (Acari: Tetranychidae) when applied to rock wool substrate [46].

\section{Conclusion}

Although the neem-based products evaluated were not able to repel and inhibit food intake of $B$. tabaci adults completely, they limited the feeding activity. The antifeedant effects of Conserve (spinosad) were much less than neem-based insecticides. Repellency and antifeedant properties conferred by these products offers novel and effective approaches to vector and disease management by rendering plants less attractive or acceptable to pest insects. Making use of the systemic properties of some natural insecticides, as demonstrated herein, perhaps can help to overcome the fast degradation due to strong ultra-violet light, thereby prolonging their efficacy.

\section{References}

[1] Anonymous. (2010). National Agricultural Information System. http://nais-jordan. gov.jo /about.

[2] Perring, T. M. (2001). The Bemisia tabaci species complex. Crop Protection, 20: 725-737.

[3] Jones, D. R. (2003). Plant viruses transmitted by whiteflies. European Journal of Plant Pathology, 109: 195-219.

[4] Cohen, S., Frank, E., Doyle, W. J., Skoner, D. P., Rabin, B. S. and Gwaltuey, J. M. Jr. (1998). Types of stressors that increase susceptibility to the common cold in healthy adults, Journal of Health Psychology. 17: 214-223.

[5] Abou-Fakhr, H. E. M., Nemer, N. M., Hawi, Z. K. and Hanna, L. T. (2000). Responses of the sweetpotato whitefly, Bemisia tabaci, to the Chinaberry tree (Melia azedarach L.) and its extracts. Annals of Applied Biology, 137: 79-88.

[6] Rapisarda, C. and Tropea Garzia, G. (2002). Tomato yellow leaf curl Sardinia virus and its vector Bemisia tabaci in Sicilia (Italy): present status and control possibilities. EPPO Bulletin, 32: $25-29$.

[7] Berlinger, M. J., 1986, Host plant resistance to Bemisia tabaci. Agriculture, Ecosystem and Environment, 17: 69-82.

[8] Kaloshian, I. and Walling, L. L. (2005). Hemipterans as plant pathogens. Annual Review of Phytopathology, 43: 491-521.

[9] Walling, L. L. (2008). Avoiding effective defenses: strategies employed by phloem-feeding insects, Plant Physiology, 146: 859-66.

[10] Coudriet, D. L., Prabhaker, N., Kishaba, A. N. and Meyerdirk, D. E. (1985). Variation in developmental rate on different hosts and overwintering of the sweet potato whitefly, Bemisia tabaci (Homoptera: Aleyrodidae). Environmental Entomology, 14: 516-519.

[11] Kim, H. G., Jeon, J. H., Kim, M. K. and Lee, H. S. (2005). Pharmacological effects of asaronaldehyde isolated from Acorus gramineus rhizome. Food Science and Biotechnology, 14: 685-688.

[12] Rembold, H. (2002). Effect on viruses and organisms: Insectgrowth and metamorphosis, in: Schmutterer, H. (Eds.), The Neem Tree, Vithalnagar, Juhu Schema, Mumbai, Neem foundation, pp. 237-254.

[13] Cavalcante, G. M., Moreira, A. F. C. and Vasconcelos, S. D. (2006). Potencialidade inseticida de extratos aquosos de essências florestais sobre mosca-branca. Pesquisa Agropecuária Brasileira, 41: 9-14.

[14] Kumar, P., Poehling, H-M. and Borgemeister, C. (2005). Effects of different application methods of neem against sweet potato whitefly Bemisia tabaci Gennadius (Homoptera: Aleyrodidae) on tomato plants. Journal of Applied Entomology, 129: 489-497.

[15] Kumar, P. and Poehling, H-M. (2006). Persistence of soil and foliar azadirachtin treatments to control sweet potato whitefly Bemisia tabaci Gennadius (Homoptera: Aleyrodidae) on tomatoes under controlled (laboratory) and field (netted greenhouse) conditions in the humid tropics, Journal of Pest Sciences, 79: 189-199. 
[16] Kumar, P. and Poehling, H-M. (2007). Effects of azadirachtin, abamectin, and spinosad on sweetpotato whitefly (Homoptera: Aleyrodidae) on tomato plants under laboratory and greenhouse conditions in the humid tropics. Journal of Economic Entomology, 100: 411-420.

[17] Souza, A. P. de. and Vendramim, J. D. (2005). Efeito translaminar, sistêmico e de contato de extrato aquoso de sementes de nim sobre Bemisia tabaci (Genn.) biótipo B em tomateiro. Neotropical Entomology, 34: 83-87.

[18] Pearsall, I. A. and Hogue, E. J. (2000). Use of azadirachtin as a larvicide or feeding deterrent for control of western flower thrips in orchard systems. Phytoparasitica, 28: 219-228.

[19] Gerald, W. (2001). Actions of insecticidal spinosyns on gamaaminobutyric acid responses for small-diameter cockroach neurons. Pesticide Biochemistry and Physiology, 71: 20-28.

[20] Mark, H., Thompson, G. D., Subramanyam, B. and Athanassiou, C. G. (2011). Spinosad: A new natural product for stored grain protection. Journal of Stored Product Research, 47: 131-146.

[21] SAS Institute. (2000). SAS statistics user's manual, SAS version 9.2. NC: SAS Institute, Inc. Cary.

[22] Püntener, W. (1981). Manual for Field trials in Plant Protection, Agric. Div, Ciba-Geigy Limited, Basle, Switzerland. p. 205.

[23] McCloskey, C., Arnason, J. T., Donskov, N., Chenier, R., Kaminski, J. and Philogène, B. J. R. (1993). Third trophic level effects of azadirachtin, Canadian Entomologist, 125: 163-165.

[24] Saxena, B. P., Tikku, K., Atal, C. K. and Koul, O. (1986). Insect antifertility and antifeedant allelochemics in Adhatoda vasica, Insect Science and its Application, 7: 489-493.

[25] Saxena, R. C. and Khan, Z. R. (1988). New bioactive products: growth regulators, antifeedants, pheromones and other attractants, in: Marini-Bettòlo, G. B. (Eds.), Towards a Second Green Revolution: From Chemical to New Biological Technologies in Agriculture in the Tropics, Elsevier Science, pp. 303-317.

[26] De Nardo, E. A. B., Costa, A. S. and Lourenção, A. L. (1997). Melia azedarach extract as an antifeedant to Bemisia tabaci (Homoptera: Aleyrodidae). Florida Entomologist, 80: 92-94.

[27] Hilje, L., Stansly, P. A., Carballo, M. and Mora, G. A. (2003). Repellency and deterrency caused by plant extracts on Bemisia tabaci adults. Third International Bemisia Workshop, Barcelona, p. 103.

[28] Wen, J-H., Hou, M-L., Lu, W. and Li, J-W. (2007). Effects of azadirachtin on host selection and oviposition of sweetpotato whitefly Bemisia tabaci Gennadius. Chinese Journal of Biological Control, 44: 491-496.

[29] Wen, J-H., Lin, K-J., Hou, M-L., Lu, W. and Li, J-W. (2009). Influence of foliar and systemically applied azadirachtin on host-plant evaluation behaviour of the sweetpotato whitefly, Bemisia tabaci. Physiological Entomology, 34: 98-102.

[30] Shannag, H. K., Capinera, J. L. and Freihat, N. M. (2013). Use of neem-based insecticides against southern armyworm, Spodoptera eridania (Stoll) (Lepidoptera: Noctuidae). Trends in Entomology, 9: 45-53.
[31] Shannag, H. K., Capinera, J. L. and Freihat, N. M. (2014). Efficacy of different neem-based biopesticides against green peach aphid, Myzus persicae (Hemiptera: Aphididae). International Journal of Agricultural Policy and Research, 2: 061-068.

[32] Lowery, D. T., Isman, M. B. and Brard, N. L. (1993). Laboratory and field evaluation of neem for the control of aphids (Homoptera: Aphididae). Journal of Economic Entomology, 86: 864-870.

[33] Griffiths, D. C., Pickett, J. A., Smart, L. E. and Woodcock, C. M. (1989). Use of insect antifeedants against aphid vectors of plant virus disease. Journal of Pest Science, 27: 269-276.

[34] Jenkins, D. A., Dunkel, F. V. and Gamby, K. T. (2003). Storage temperature of neem kernel extract: Differencial effects on oviposition deterrency and larval toxicity of Callosobruchus maculatus (F.) (Coleoptera: Bruchidae). Environmental Entomolology, 32: 1283-1289.

[35] Klocke, J. A., Balandrin, M. F., Barnby, M. A., Yanasaki, R. B., 1989, Limonoids, phenolics and furanocoumarins as insect antifeedants, repellents and growth inhibitory compounds, in: Arnason, J. T., Philogene, B. J. R., Morand, P. (Eds.) Insecticides of plant origin, ACS Symposium Series 387, pp. 136-149.

[36] Barnby, M. A. and Klocke, J. A. (1987). Effects of azadirachtin on the nutrition and development of the tobacco budworm, Heliothis virescens (Fabr.) (Noctuidae). Journal of Insect Physiology, 33: 69-75.

[37] Mordue, A. J. and Nisbet, A. J. (2000). Azadirachtin from the neem tree Azadirachta indica: its actions against insects. Anais da Sociedade Entomológica do Brasil, 29: 615-632.

[38] Kleeberg, H. (1992). The NeemAzal conception test of systemic activity, in: Kleeberg, H. (Eds.), Proceedings of the 1st Workshop on Practice Oriented Results on Use and Production of Neem Ingredients, 19-20 June 1992, Druck and Graphic, Giessen, Germany Wetzlar, Germany, pp. 5-15.

[39] Otto, D. (1994). Effects of the azadirachtin preparation "NeemAzal-W" on larvae and adults of Leptinotarsa decemlineata, in: Kleeberg, H. (Eds.), Practice Oriented Results on Use and Production of Neem-Ingredients and Pheromones, Druck und Graphic, Giessen, Germany, pp. 3953.

[40] Weintraub, P. G. and Horowitz, A. R. (1997). Systemic effect of a neem insecticide on Liriomyza huidobrensis. Phytoparasitica, 25: 283-289.

[41] Prabhaker N, Toscano N. C. and Henneberry T. J. (1999). Comparison of neem, urea, and amitraz as oviposition suppressant and larvicides against Bemisia argentifolii (Homoptera: Aleyrodidae). Journal of Economic Entomology, 92: $40-46$

[42] Thoeming, G., Borgemeister, C., Sétamou, M. and Poehling, H-M. (2003). Systemic effects of neem on western flower thrips, Frankliniella occidentalis (Thysanoptera: Thripidae). Journal of Economic Entomology, 96: 817-825.

[43] Ossiewatsch, H. R. (2000). Zur Wirkung von SamenkernWasserextrakten des Niembaumes Azadirachta indica (A Juss.) auf Blattlaeuse und ihre natuerlichen Gegenspieler. $\mathrm{Ph}$. D. dissertation. Justus-Liebig University Giessen Germany. 
[44] Larew, H. G. (1988). Limited occurrence of foliar-, root- and seed-applied neem seed extract toxin in untreated plant parts. Journal of Economic Entomology, 81: 593-598.

[45] Van Leeuwen, T., Van de Veire, M., Dermauw, W. and Tirry, L. (2006). Systemic toxicity of spinosad to the greenhouse whitefly Trialeurodes vaporariorum and to the cotton leaf worm Spodoptera littoralis. Phytoparasitica, 34: 102-108.
[46] Van Leeuwen, T., Dermauw, W., Van De Veire, M. and Tirry, L. (2005). Systemic use of spinosad to control the two-spotted spider mite (Acari: Tetranychidae) on tomatoes grown in rockwool. Experimental and Applied Acarology, 37: 93-105. 